\title{
Interactions between cetaceans and artisanal fishermen from Ilhéus, Bahia - Brazil
}

\author{
Cecilia Inés Seminara ${ }^{a}$, Márcio Luiz Vargas Barbosa-Filho ${ }^{b}$ \& Yvonnick Le Pendu ${ }^{c}$ * \\ ${ }^{a}$ Universidade Estadual de Santa Cruz, Programa de Pós-Graduação em Zoologia, Ilhéus, BA, Brasil \\ ${ }^{b}$ Universidade Federal Rural de Pernambuco, Programa de Pós-Graduação em Etnobiologia e Conservação da \\ Natureza, Recife, PE, Brasil \\ 'Universidade Estadual de Santa Cruz, Departamento de Ciências Biológicas, Ilhéus, BA, Brasil \\ *Corresponding author: Yvonnick Le Pendu, e-mail: yvonnick@uesc.br
}

SEMINARA, C.I., BARBOSA-FILHO, M.L.V., LE PENDU, Y. Interactions between cetaceans and artisanal fishermen from Ilhéus, Bahia - Brazil. Biota Neotropica. 19(4): e20190742. http://dx.doi.org/10.1590/16760611-BN-2019-0742

\begin{abstract}
Ethnobiological studies are necessary to understand the relationships between fishers and cetaceans. The aim of this study was to describe the interactions between cetaceans and artisanal fishers and the possible conflicts that can arise as a result. Semi-structured interviews were conducted from February to September 2017 with 35 fishermen from the municipality of Ilhéus, Brazil. All fishermen reported both positive and negative interactions with Megaptera novaeangliae, Tursiops truncatus and Sotalia guianensis and only negative interactions with Balaenoptera acutorostrata $(\mathrm{n}=14)$ and Stenella frontalis $(\mathrm{n}=4)$. The positive interactions consisted of playful relationships and collaborative fishing. Negative interactions (bycatch, entanglement, collisions) affect both the fishermen and cetaceans. S. guianensis is the species most affected by bycatch in fishing nets and M. novaeangliae by entanglement and collision with vessels. The results of this study highlight the value of bringing together scientific and fishing communities to understand conflicts by monitoring interactions in order to assess the impact of fishing activity on cetacean populations. Fishers have a positive perception of cetaceans, know the areas where accidents occur and would like to avoid them. They can contribute to research on these animals and to the development of management plans appropriate to the local reality. This points out the need to integrate scientific and local knowledge for the conservation of cetaceans and for the sustainability of fishing practices.
\end{abstract}

Keywords: ethnobiology marine mammals, bycatch, entanglement, collision.

\section{Interações entre cetáceos e pescadores artesanais de Ilhéus, Bahia - Brasil}

Resumo: Estudos etnobiológicos são necessários para conhecer as relações entre pescadores e cetáceos. O objetivo deste trabalho foi descrever as interações entre cetáceos e pescadores artesanais e possíveis conflitos decorrentes destas. Entrevistas semiestruturadas foram aplicadas de fevereiro a setembro de 2017 a 35 pescadores do município de Ilhéus, Brasil. Todos os pescadores relataram interações positivas e negativas com Megaptera novaeangliae, Tursiops truncatus e Sotalia guianensis e interações somente negativas com Balaenoptera acutorostrata $(\mathrm{n}=14)$ e Stenella frontalis $(\mathrm{n}=4)$. As interações positivas se referem a relações lúdicas e pesca colaborativa. Interações negativas (emalhe, emaranhamento, colisão) afetam os pescadores e os cetáceos. S. guianensis é a mais afetada por emalhes em redes de pesca e M. novaeangliae por emaranhamento e colisão com embarcações. Os resultados deste estudo destacam o valor de reunir comunidades científicas e pesqueiras para compreender os conflitos através da monitorização das interações, a fim de avaliar o impacto das atividades de pesca nas populações de cetáceos. Os pescadores possuem uma percepção positiva sobre os cetáceos, conhecem as áreas onde ocorrem os acidentes e gostariam de evita-os. Eles podem contribuir para as pesquisas sobre estes animais e a elaboração de planos de manejo adequados a realidade local. Isto aponta a necessidade da integração de conhecimentos científicos e locais para a conservação dos cetáceos e para a sustentabilidade das práticas da pesca.

Palavras-chave: etnobiologia, mamiferos marinhos, emalhe, emaranhamento, colisão. 


\section{Introduction}

Interactions occur between fishers and cetaceans as a result of fishing grounds overlapping the areas frequented by the animals. The intensity and frequency of these interactions may be increasing as a result of an increasing fishing effort and the growth of cetacean populations (Northridge 1984, De Master et al. 2001, Read et al. 2006, Silva et al. 2014). In Brazil, the banning of commercial whaling in 1987 (Law 7643), along with other conservation measures, has resulted in the growth of humpback whale (Megaptera novaeangliae, Borowski, 1781) (Andriolo et al. 2010, Ward et al. 2011) and southern right whale (Eubalaena australis, Desmoulins, 1822) (Groch 2005) populations. This population growth, in turn, is a potential source of conflict.

Ethnobiological studies emphasize the importance of deepening the analysis of interactions between fishers and cetaceans in order to estimate the extent of these interactions and provide new information about these animals (e.g. Alarcon et al. 2009, Zappes et al. 2013a, Lenney et al. 2015). These interactions may lead to insecurity and economic losses for fishers as a result of reduced catches and damage to fishing gear (Zambonim et al. 2009, Zappes et al. 2011b); injuries or death of cetaceans from collisions with fishing boats (Marcondes \& Engel 2009, Zappes et al. 2013b); intentional (Barbosa-Filho et al. 2016) or accidental capture (bycatch) (Freitas-Netto \& Di Beneditto 2008, Silva et al. 2014, Manzan \& Lopes 2015, Revuelta et al. 2018). Damage to fishing gear usually occurs when cetaceans are caught accidentally (Freitas-Netto \& Di Beneditto 2008, Zappes et al. 2011b) or when travelling migratory species drag and destroy fishing equipment (Pinheiro \& Cremer 2003, Zambonim et al. 2009, Zappes et al. 2013a). In most cases, the carcasses of cetaceans that are accidentally killed are discarded at sea, but they may be used for human consumption or for use as bait (Zappes et al. 2009, Souza 2011, Lenney et al. 2015, Barbosa-Filho et al. 2018).

There are also benefits for fishers arising from their interaction with cetaceans. For example, it has been reported that bottlenose dolphins (Tursiops truncatus) can indicate the location of fish shoals to fishers (Peterson et al. 2008, Zappes et al. 2011a). On the other hand, the interaction can be positive for the cetaceans, which can catch fish directly from the fishing gear and thus save energy that would be needed for fishing (e.g. Orca, Orcinus orca, Dalla-Rosa \& Secchi 2007).

Integrating fishers's knowledge into scientific research may be the only way to ensure the quality and accessibility of the data that only they can provide. A contextualized analysis that is connected to local realities allows better understanding of the natural systems and people's relations with them (Diegues 2000). This understanding can support the planning of more appropriate management strategies for local natural resources (Carlsson \& Berkes 2005). Scientific knowledge of the majority of cetacean species occurring in Bahia is still scarce: 14 species are classified as "Insufficient Data" with regards to their conservation status (Cassano et al. 2017). The increase in humpback whale sightings reported by fishers in the region (Souza 2015) suggests that encounters with the species have increased. Fishing is small-scale and artisanal in the Ilhéus region: the fishing fleet is made up of saveiro boats varying from 6-9 $\mathrm{m}$ in length for line fishing and from $10-15 \mathrm{~m}$ in length for trawling (Barbosa-Filho \& Cetra 2007). In light of the above, this study aims to assess whether there is an overlap between the fishing grounds and the areas visited by cetaceans, to describe and analyze interactions and to identify possible conflicts between cetaceans and the artisanal fishers of Ilhéus.

\section{Material and Methods}

\section{Study area}

The municipality of Ilhéus $\left(14^{\circ} 48^{\prime} \mathrm{S} ; 39^{\circ} 01^{\prime} \mathrm{W}\right)$ is located on the southern coast of the state of Bahia, in the northeast of Brazil. In this municipality there are two Fishers's Colonies (Z-19 and Z-34), as well as the Fishers and Shellfish Association of São Miguel (A-87) (Figure 1). The municipality of Ilhéus was chosen for this study because fishing is an important economic activity (Queiroz 2012) and because of the occurrence of a wide variety of cetacean species in the region (Cassano et al. 2017, Batista et al. 2012).

The width of the continental shelf ranges between $6 \mathrm{~km}$ in the municipality of Itacaré, located $50 \mathrm{~km}$ to the north of Ilhéus and $17.5 \mathrm{~km}$ on the Royal Charlotte Bank, situated $130 \mathrm{~km}$ south of Ilhéus. The shelf consists of a sand and sandy mud seabed in the shallower areas (up to $10 \mathrm{~m}$ depth), followed by mixed muddy sediments (up to $20 \mathrm{~m}$ depth). At the edge of the continental shelf break (50 to $70 \mathrm{~m}$ depth) muddy sediments and biodetritic sands predominate (Bittencourt et al. 2000).

\section{Data collection}

A qualitative approach is appropriate to conduct studies on cultural perception of members of local community, because the method allow the researchers to approximate the subjects of study and better understand the social, historical and cultural context of the community (Zappes et al. 2013a). According to Mason (2010) a qualitative research is concerned with meaning. Thus, frequencies are rarely important, the occurrence of a data is as useful as many in the understanding of the subjective process of a community.

Sample size in qualitative research designs is highly variable (Marshall et al. 2013). In this study, the researcher (first author) conducted oral interviews with 35 fishermen. This number of interviewees is comparable to other ethnobiological studies on on perceptions of cetaceans by communities in Brazil, as: Souza \& Begossi (2007) with an average of five respondents in each community in Sao Sebastião, state of São Paulo; Zappes et al. (2009) with 20 interviews in each area studied in Bahia, Espírito Santo, Rio de Janeiro and São Paulo; Zappes et al. (2011a) with 22 artisanal fishermen in Barra de Imbé/ Tramandaí, Southern Brazil; Zappes et al. (2011b) with 22 respondents in Rio de Janeiro; Amorim et al. (2012) with 20 interviews in Rio de Janeiro, Costa et al. (2012) with 22 in Canavieiras, Bahia; Zappes et al. (2013a) with 33 ethnographic interviews in Garopaba, Santa Catarina; Manzan \& Lopes (2015) with an average of 38 in each community of Rio Grande do Norte.

Data collection began after approval was given by the Ethics Committee (CEP-CONEP n ${ }^{\circ}$ 68007516.9.0000.5526). The nature and purpose of the research was explained to each fisher and they were each provided with a Free and Informed Consent Form, in order to establish whether they would like to contribute to the research, with permission requested for anonymous recording of information. 
Interactions between cetaceans and artisanal fishermen from Ilhéus, Bahia - Brazil

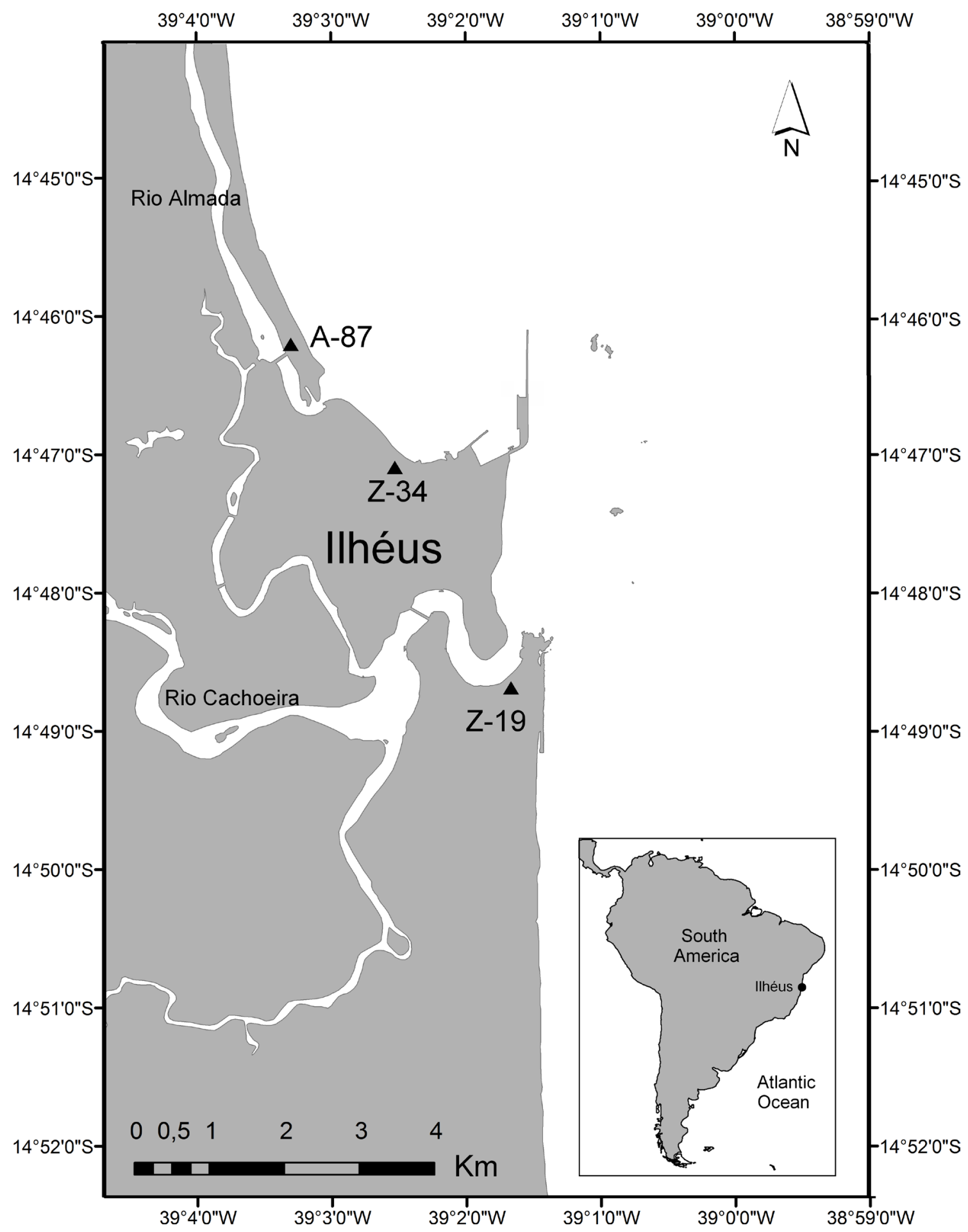

Figure 1. Geographical location of Ilhéus and the Z-19 Fishing Colony in Pontal, Fishing Colony Z-34 in Malhado, and the Fishers and Shellfish Association of São Miguel (A-87) in Ilhéus, Bahia, Brazil.

We conducted a pilot study in February 2017 to test and calibrate the questionnaire. The questions were adjusted to improve the understanding, cultural acceptance and the usual vocabulary used by the fishers in the study area and to improve the interpretation of the data (Fontanella et al. 2011). The interviews considered for analyses were conducted between March and September 2017 and took place on streets, beaches, squares, and fishers' association headquarters. Each interview lasted for about an hour. The interruption of the interviews occurred when the researcher verified the scarcity of new types of statements, based on the empirical data already collected and on her analytical and interpretative attributes. The collection of new data by additional interviews would not necessarily add new information for discussion in relation to the theoretical density already obtained for the research objectives (Mason 2010; Fontanella et al. 2011; Marshall et al. 2013). 
The first interviewees were the fishers considered by the presidents of the colonies as having the greatest and most detailed knowledge of the regional fishing context. The non-probability "snowball" sampling method (Biernacki \& Waldorf 1981) was then applied, which involved each fisher indicating another with recognized skill as a fisher. Only artisanal fishers with at least 15 years of fishing experience and who have resided in the municipality for more than 10 years were interviewed. These criteria were considered reasonable for acquiring accurate knowledge of the dynamics and components of the marine ecosystem (Souza \& Begossi 2007).

Semi-structured interviews were conducted (Albuquerque et al. 2014), the questionnaire consisted of open (25) and closed (20) questions, addressing socioeconomic aspects of local fishing (age, time as a fisher, time of residence in the study area, schooling level, characteristics of the vessels) and the interactions between fisheries and cetaceans: local name, positive and negative interactions, local of interactions, behavior, accidents related to vessels and animals (bycatch, intentional use of cetaceans by fishers for baiting and other uses).

Fishermen were visually stimulated (Medeiros et al. 2014) to investigate their ability to distinguish the cetaceans that occur in their fishing territory and to indicate interactions with fishing activity). We used 19 boards each containing four different photographs of 19 cetacean species previously recorded in the study area (Rocha-Campos et al. 2011, Monteiro-Filho et al. 2013, Cassano et al. 2017): Suborder Misticeti: Eubalaena australis, Megaptera novaeangliae, Balaenoptera acutorostrata (Lacépède, 1804), B. edeni (Anderson, 1879) and B. physalus (Linnaeus, 1758); Suborder Odontoceti: Physeter macrocephalus (Linnaeus, 1758), Orcinus orca (Linnaeus, 1758), Globicephala macrorhynchus (Gray, 1846), Feresa atenuatta (Gray, 1870), Pseudorca crassidens (Owen, 1846), Peponocephala electra (Gray, 1846), Tursiops truncatus (Montagu, 1821), Sotalia guianensis (Van Beneden, 1864), Steno bredanensis (Gray, 1846), Stenella attenuata (Gray, 1846), S. frontalis (Cuvier, 1829), S. clymene (Gray, 1846), and S. longirostris (Gray, 1828). The fransiscana dolphin Pontoporia blainvillei (Gervais \& d'Orbigny, 1844), which has not been recorded in Bahia, was included as a control species in order to verify whether fishers would recognize this fact. Each board was shown to the fisherman. When he affirmed to recognize the depicted animal, he was questioned about the common name and the interactions with that animal.

Nine of the 35 interviewees were invited to elaborate a participatory mapping (da Silva \& Verbicaro 2016, Gerhardinger et al. 2010). The fishermen drew on the nautical chart 1200 (Port of Ilhéus to Ponta Cumuruxatiba) scale 1:305090 (BRASIL 1979), provided by themselves, the location of the fishing areas previously cited during the interviews and navigation routes. They were also encouraged to mark the places where they usually observe humpback whales and where accidents with this species have already occurred. The participatory mapping of marine territory and accident areas has been chosen as a way to contribute to the conservation goals and actions of the IWC (International Whaling Commission) and the National Plan of Action for the Conservation of Marine Mammals, among them, to evaluate the impacts of the fishing activity on cetaceans and to identify the main areas of overlap (Rocha-Campos et al. 2011, IWC 2016). The local knowledge of fishermen is an efficient way to quickly fill this gap.

\section{Data analysis}

The data obtained from the interviews was analyzed using the model of identification of covert categories, in which all information pertinent to the research is considered (Hays 1976). The fishers could choose not to respond or to provide more than one answer to each question. Descriptive statistics (means and frequencies) were calculated using the number of responses as the criterion (Silvano \& Begossi 2002).

The nautical chart drawn by the nine fishermen was digitalized and georeferenced using ArcGis 10.3, generating a map of the marine territory used by the community for fishing and the main areas of occurrence of accidents with humpback whales.

A Kernel density map was generated with the interpolation tool of Geostatistical Analyst Tools, an extension of ArcGis 10.3, using the fishing ground where the 35 fishermen sighted cetaceans. These coordinates were georeferenced on a map of the cartographic base in a SIG environment; then the Kernel density estimator was applied, which generated a density surface of the visual identification of areas of sightings, based on the number of citations for each fishing ground. The GPS points of the humpback whale accident sites were provided by the fishermen's colony and plotted on the map.

\section{Results}

Thirty-five male fishers aged $25-82$ years $($ mean $=51$, standard deviation $=10$ ) were interviewed, predominantly in the $45-54$ years age group (Figure 2a). Time spent fishing ranged from 16 to 74 years (mean $=33$, standard deviation $=11$ ), with fishermen with 35 to 44 years of experience being the most frequent (Figure 2b). The schooling level of the interviewees is considered low, with $75 \%(n=26)$ currently illiterate, having never been to school or not having completed elementary school. The majority of the fishermen ( $\mathrm{n}=21 ; 60 \%)$ were born in Ilhéus, while the others are from neighboring municipalities in the interior of Bahia $(n=8)$ and other states $(n=6)$.

The fishing grounds used by fishermen from Ilhéus cover $190 \mathrm{~km}$ of

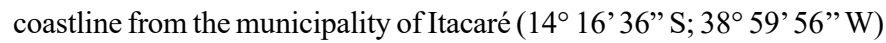
in the north to Belmonte ( $15^{\circ} 51$ ' $47^{\prime \prime} \mathrm{S} ; 38^{\circ} 52^{\prime} 58^{\prime \prime} \mathrm{W}$ ) in the south. The time spent at sea by the boats per trip varies from 7 to 9 days. The fishermen also carry out one-day trips, called "bate e volta" ("there and back"), to check the nets. The crew usually consists of four fishermen. Most vessels are equipped with VHF radio for communication and with GPS, compass and fishfinder for the location of the fishing grounds, located mainly on the continental shelf and continental slope.

The fishermen interviewed reported fishing-related interactions with five of the 19 species of cetaceans presented: M. novaeangliae (humpback whale), T. truncatus (common bottlenose dolphin), S. guianensis (Guiana dolphin), B. acutorostrata (dwarf minke whale) and $S$. frontalis (Atlantic spotted dolphin), known locally as: Baleia, Golfinho, Boto, Tauaçu and Pinta-preta, respectively. None of the participants reported having seen the franciscana dolphin P. blainvillei (control species) in the region.

\section{Positive interactions}

All of the respondents believe that the existence of cetaceans is important for conservation of the marine environment and most of 


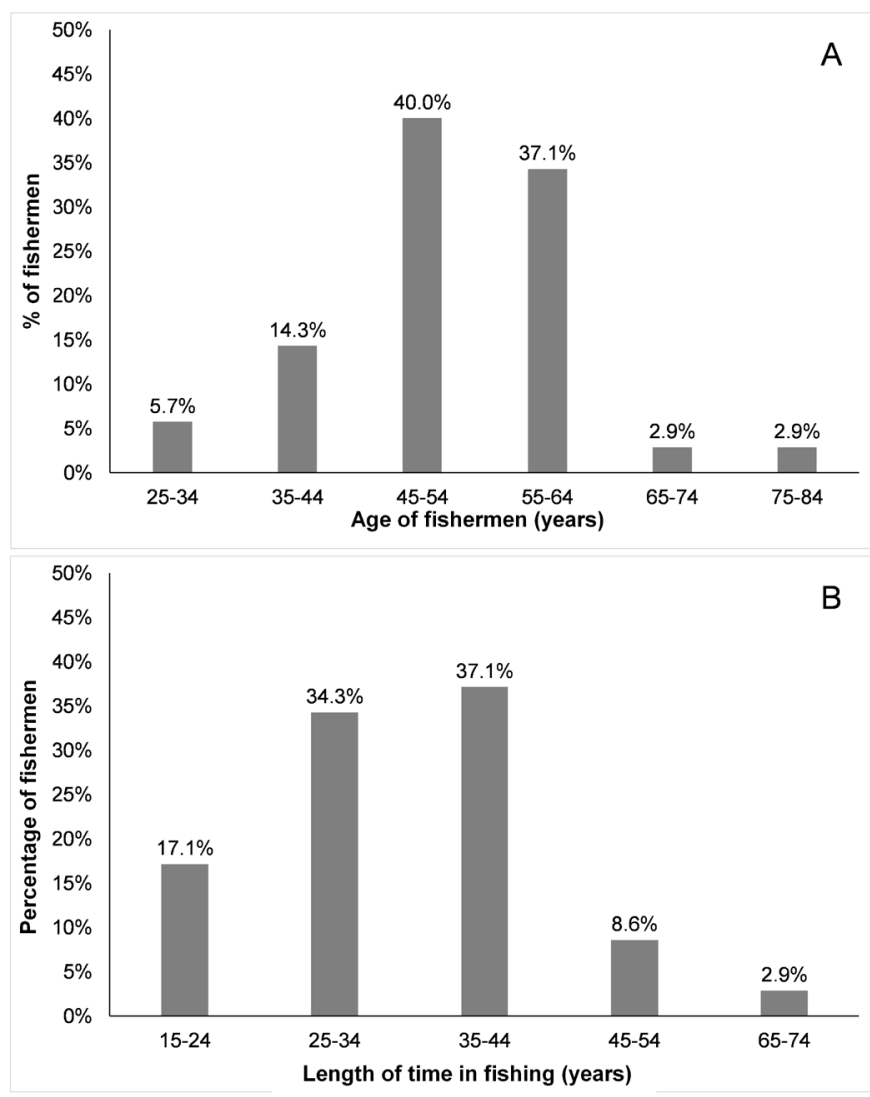

Figure 2. Age (A) and length of time in fishing (B) of the 35 artisanal fishermen interviewed in Ilhéus.

them $(n=32 ; 91.43 \%)$ stated that they enjoy watching these animals and their behavioral displays. Positive interactions were reported with bottlenose dolphins, Guiana dolphins and humpback whales.

All of the fishermen cited at least one type of behavior for humpback whales and bottlenose dolphins, and $40 \%$ of them mentioned some kind of display for Guiana dolphins. The behaviors observed most often among Guiana dolphins were: "jump, roll, play, pass by swimming, show the upper flipper and dive" $(\mathrm{n}=14)$ (Table 1). They described both diurnal and nocturnal behavior for bottlenose dolphins (Table 2) and for humpback whales (Table 3). The most frequent behavior for bottlenose dolphins during day and night was "swimming alongside the boat, at about 6 knots, then swimming near the prow of the boat and jumping clear of the water before going back to swimming alongside the boat again, it's funny, they are our friends, they distract us" (I. 50 years). Two of the behaviors reported refer to the use of parts of the boat: "When the boat is anchored, they wrap themselves around the anchor line to scratch themselves, they circle around it, and then go down" and "they wrap themselves around the anchor line and pull the boat along, they are strong, they pull it about $3 \mathrm{~m}$, and then let go, and then do it again".

Breaching was the most common behavior for humpback whales during the day, while "at night they are quieter" (Table 2).

Fishermen fishing on the riverbanks or in the river reported that Guiana dolphins show them where the fish are and drive them towards the bank $(\mathrm{n}=3)$, they describe how "the boto swims above the fish and
Table 1. Number of mentions $(\mathrm{n}=14)$ for behaviors displayed by Guiana dolphins and reported by fishermen from Ilhéus-BA.

\begin{tabular}{lc}
\hline Observed behaviors & Number of citations \\
\hline Jump & 10 \\
Play & 6 \\
Roll & 2 \\
Pass by swimming & 2 \\
Show the upper flipper & 2 \\
Dive & 1 \\
\hline
\end{tabular}

Table 2. Number of mentions of diurnal $(n=35)$ and nocturnal $(n=25)$ behaviors displayed by bottlenose dolphins and observed by fishermen from Ilhéus, Bahia.

\begin{tabular}{lcc}
\hline \multirow{2}{*}{ Observed behaviors } & \multicolumn{2}{c}{ Number of citations } \\
\cline { 2 - 3 } & Day & Night \\
\hline Bow-riding & 31 & 9 \\
Breaching & 26 & 1 \\
Playing with the anchor line & 11 & 5 \\
Play & 11 & - \\
Whistling, making "piiiii" sound & 10 & - \\
Twisting, pulling the boat & 3 & 2 \\
Tail-slapping & 2 & 2 \\
Lifting head in and out of the water & 1 & - \\
Spyhopping & 1 & - \\
Spinning in the air & 1 & - \\
\hline
\end{tabular}

Table 3. Number of mentions of diurnal $(n=35)$ and nocturnal $(n=25)$ behaviors displayed by the humpback whale and observed by fishermen from Ilhéus, Bahia.

\begin{tabular}{lcc}
\hline \multirow{2}{*}{ Observed behaviors } & \multicolumn{2}{c}{ Number of citations } \\
\cline { 2 - 3 } & Day & Night \\
\hline Breach, spinner-breaching & 35 & 9 \\
Tail-slapping & 14 & - \\
Tail up, head down & 15 & 1 \\
Flipper-slapping & 7 & 1 \\
Play with others & 4 & - \\
Stopped and looking at us & 5 & \\
Floating on one side with one flipper out & 4 & - \\
Swimming/passing by & 4 & 7 \\
Lifting head and slapping & 3 & - \\
Lifting both flippers out of the water, open & 3 & - \\
Floating & 2 & - \\
Spraying & 2 & 8 \\
Becoming quieter, sleeping on the surface & & 6 \\
Bellowing & 13 & 6 \\
\hline
\end{tabular}

starts to jump, when this happens, we know that there are fish" (M. 25 years). They also reported that bottlenose dolphins round up schools of fish $(\mathrm{n}=4)$, "they swim around the boat, they round up the school of small fish that we use for bait, then we catch them" (N. 57 years). 
Guiana and bottlenose dolphins were mentioned as being protectors of fishermen at sea: "If you are drowning the boto pushes you to land" $(\mathrm{n}=2)$. "The golfinho saves us, he does not let sharks attack you, he is the bravest animal in the sea" $(\mathrm{n}=11)$. According to the respondents $(\mathrm{n}=6)$, Guiana dolphins, bottlenose dolphins and humpback whales also warn of a change in the weather:

When a thunderstorm is coming, the baleia breaches, and swims around in circles. The golfinho is the same, it slaps the water with its tail, after this a cold front will arrive within two days. When it is windy they like to play, when the weather is getting worse they are happy. The boto is the same, they beat their tails at the Pedra da Concha (A. 63 years).

\section{Negative interactions}

Most of the respondents ( $\mathrm{n}=33 ; 94.29 \%)$ know of the existence of the law protecting these animals from capture and harassment (Law 7643/1987) and say that they respect it. However, negative interactions were reported.

Four fishermen reported the intentional harpooning of bottlenose and Atlantic spotted dolphins and explained that this still happens today:

The pinta-preta is often harpooned for use as bait for bottom longlining, it is good for snapper, grouper, shark, swordfish (A. 46 years).

They catch them for shark bait, the smell attracts sharks. The golfinho come very close to the boat, it's the same with the people here from Ilhéus and from elsewhere too, Valença, Alcobaça and Vitoria. It happens all the time, even today (P. 48 years).

The animals most cited for disrupting fishing were: the humpback whale for getting caught on the line or rope and the minke whale for coming close to the boat and because there is a belief that they attack fishermen (Figure 3). The minke whale was described as "the most distressing, a very angry creature", considered "very dangerous", it scares all of the respondents who recognized the animal $(n=14$; $100 \%$ ),

It is treacherous, if someone is sitting on the edge, it comes from behind, it wants to devour the person. It is the most dangerous animal in the sea. You have to move to another spot, it does not flee when it hits the boat, it pulls the anchor and dives, in $35 \mathrm{~m}$ deep water, then it leaves. Every fisherman is afraid of this "fish". It scares the fish away and the people too (N. 47 years).

Most of the respondents $(n=33 ; 94.3 \%)$ have developed strategies to prevent cetaceans from disrupting fishing, to try to avoid accidents and, in the case of humpbacks and minke whales, also as a result of the fear they instill. The most frequently adopted behavior is to move to another fishing site or remove the line from the water and wait for the animals to move away from the proximity of the boat. They also hit the sides of the boat or start the engine, and at night, "we turn off the light of the boat, so that they move away, the light attracts them". Sometimes they are able to get rid of the animal without hurting it, "when the golfinho gets to be too much I throw flour, they don't like it and go away, I get rid of them without hurting them" (M. 82 years). However, sometimes the animals are injured, as quoted for the minke whale, "I threw a lead weight at its back to get it away, its nose was already wanting to pass the boat" (J. 55 years).

Despite the fishermen's strategies to ward off the animals, accidents do happen and are the result of bycatch, entanglement or collision. Bycatch in nets was mentioned for the bottlenose dolphin, humpback whale, Atlantic spotted dolphin and Guiana dolphin, with the latter being the most frequent victim (Figure 4). One fisherman (C. 55 years) explained that, "it doesn't see the net at night and its tail and fins become entangled; it cannot swim, and it dies, plenty die from the net or a hook line in the tail, the net causes a lot of harm". Respondents $(\mathrm{n}=24)$ reported that accidental capture (bycatch) often happens and

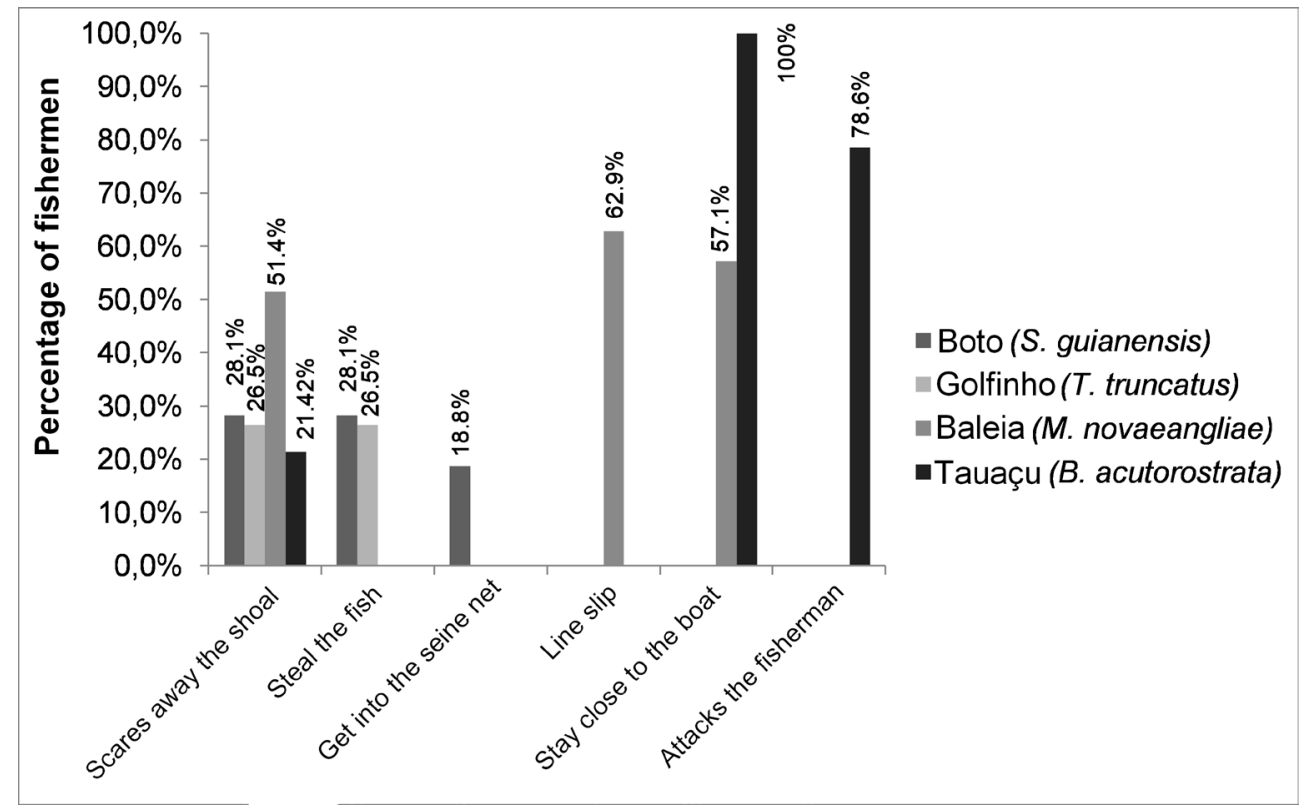

Figure 3. Ways in which the animals disrupt fishing, according to fishermen from Ilhéus, BA. 
that sometimes the animals can be released while still alive. They can also be used as bait for shark fishing $(\mathrm{n}=12)$ or the meat is cooked and eaten $(n=5)$ (Figure 5). They also discuss bycatch in ghost nets (nets lost in the sea), where they found: "turtles, golfinho, infant baleia and decomposing fish, the fish caught is wasted" (J. 45 years).

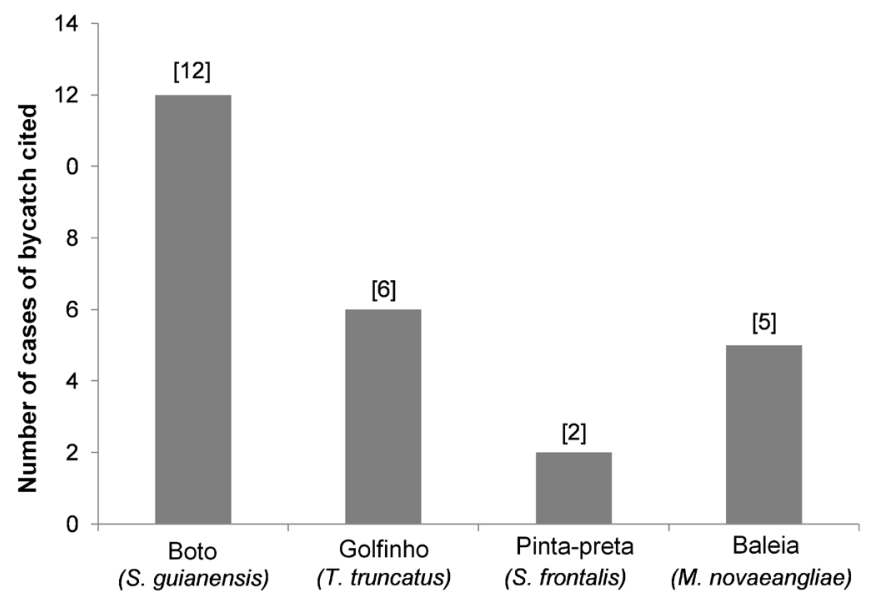

Figure 4. Number of cases of cetacean bycatch in fishing nets cited by fishermen from Ilhéus. The number of fishermen who cited the cases is enclosed in square brackets.

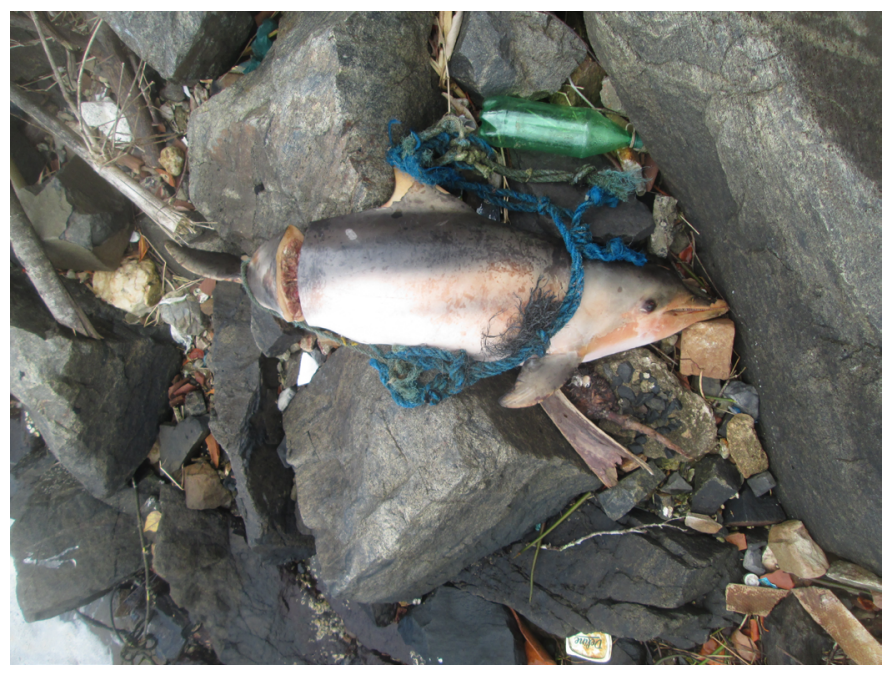

Figure 5. An adult Guiana dolphin carcass with transversal cuts in the anal region in the estuary of the Rio Cachoeira in Ilhéus (Cecilia Inés Seminara, 2013, December 26).

Entanglement was mainly cited for the humpback whale. Everyone explained that as it swims by it gets caught and drags the line until it breaks. However, the rope does not break "when it gets caught in the anchor line it gets scared and dives, pulling the boat. The fisherman who fishes on the bow of the boat has to act quickly in order to cut the anchor line and we lose the line and the iron (anchor), otherwise it can sink the vessel" (M. 48 years). This interaction may cause injury to the animal too, as one reported "the anchor cut a hole in her face" (Figure 6).

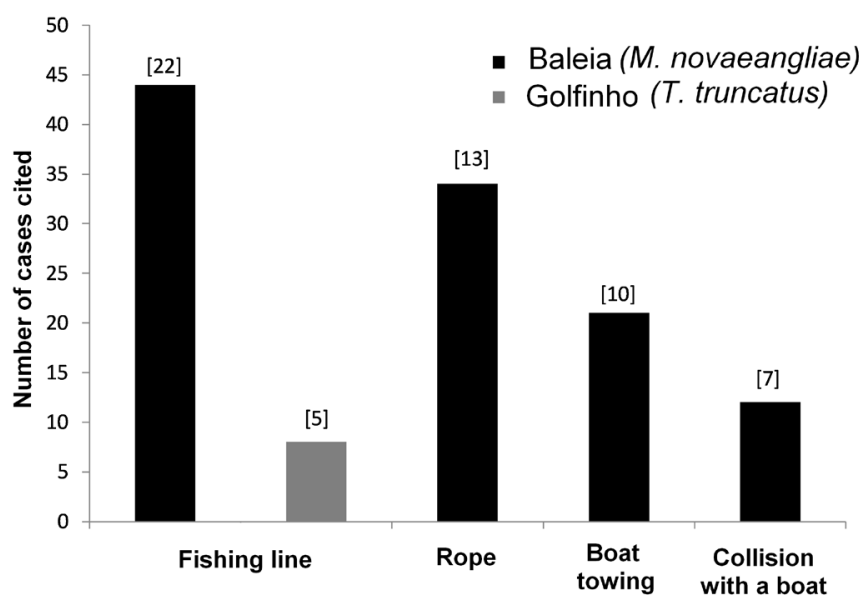

Figure 6. Number of entanglements of dolphins and whales, cited by fishermen from Ilhéus, Bahia. The number of accidents is based on the memories of the fishermen.

I have been dragged four times. It got caught on the rope, it was cool, but scary, it got tired and we cut the rope. It was a race, we passed in front of the other ships. It lasted for more than an hour, it goes by and once or twice per trip breaks our line, we lose everything (A. 63 years).

Some of the respondents $(n=25)$ stated that the quantity of humpback whales has increased in the last 10 years, mostly because "they have stopped hunting them", and, if the population continues to increase, they won't be able to work anymore because "it is harming our fishing, there has to be some control". Most fishermen ( $\mathrm{n}=24$; $68.57 \%$ ) believe that the risk of accidents is high, especially at night, and have felt threatened by humpback whales before. The main reason is a fear of the humpbacks breaking or sinking the vessel, "It is very frightening, they are so big, it is dangerous to travel at night, it smacks its tail, it scrapes against the boat, it sinks the boat, if the young one comes alongside the boat the mother throws herself onto it" (P. 52 years). The areas where there were the most reported accidents with whales are between the coast of Ilhéus and Una (Figure 7).

The majority of respondents $(\mathrm{n}=33 ; 94.3 \%)$ would like to avoid accidents with cetaceans "to avoid losing equipment and to protect the animals", but explain that "it happens, it cannot be avoided". With regards to nets, one of them said that "whoever uses nets knows that at some point a dolphin will get stuck there. Nets should be banned" (N. 47 years).

Of the fishermen interviewed, $83 \%(n=24)$ would work with whale-watching, as they already have the example of whale watching in Abrolhos, "they earn well in Caravelas" (C. 55 years), but also stated that their vessels could not carry tourists and that "my life is fishing".

\section{Discussion}

The comparison between the time spent as a fisherman and the age of the interviewees indicates that they started fishing as a child (minimum 8 years old) or adolescent. This fact evidences the difficulty of articulating 


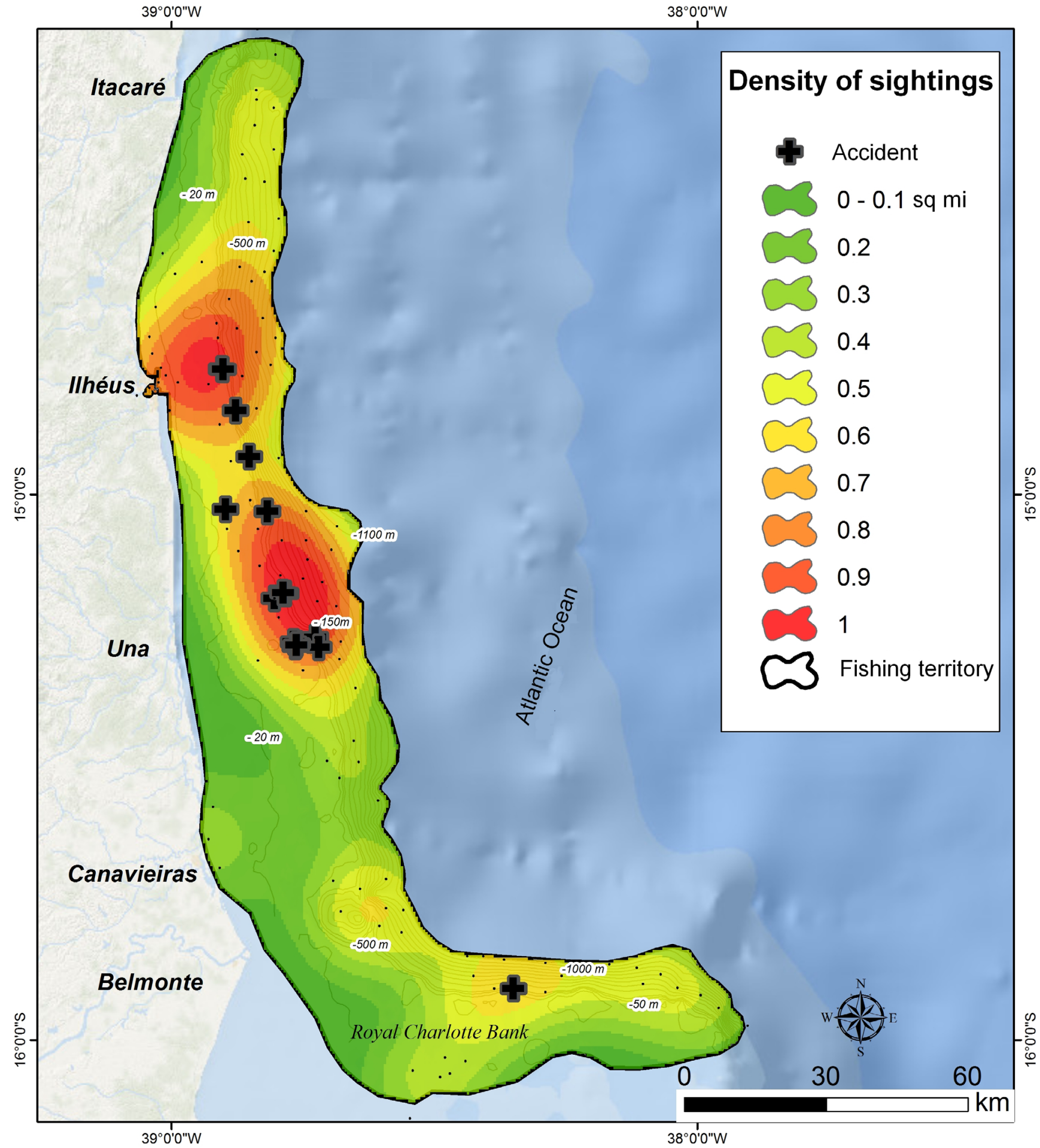

Figure 7. Map of the density of cetacean sightings by square nautical mile (SNM) and the location of occurrences of accidents with whales reported by fishermen $(\mathrm{n}=35)$ from Ilhéus, Bahia.

formal education with the socio-cultural activity, demonstrated by the low level of education presented in the study. The low level of education of this social segment is found in many of the surveys conducted on the Brazilian coast, where most fishermen have incomplete primary education (Souza 2011, Ramires et al. 2012, Silva et al. 2014). The need to dedicate oneself to fishing to obtain income and the difficulty of schools to follow a fishing calendar causes the early abandonment of formal education in the school.

The vessels used in Ilhéus are small (gross tonnage of 20 or less, BRASIL 2009), with reduced fishing technology, limited fishing autonomy and are practiced by professional fishermen. Most of the interviewees are native of Ilhéus and have all practice fishing for more 
than 15 years, which is their main source of economic income. Since they spend more than half the month at sea, they acquire detailed knowledge of the marine environment, including non-target species (Mourão et al. 2006, Alarcon et al. 2009, Zappes et al. 2010, Silva et al. 2014).

\section{Positive interactions}

The fact that the fishers enjoy watching cetacean behavior indicates that they have a positive view of them. In fact, the beauty and social behavior of cetaceans can attract people's interest and generate friendly feelings among diverse fishing communities (Zappes et al. 2010, Rodrigues \& Silva 2012).

The respondents cited a range of behaviors observed with cetaceans. The displays mentioned for $S$. guianensis correspond to the activities of socialization described by Izidoro \& Le Pendu (2012) near the Port of Ilhéus. The Guiana dolphin is mentioned proportionally less because most of the fishers operate on the continental shelf and slope while the Guiana dolphins stay closer to the coast (Borobia et al. 1991).

The behaviors cited for bottlenose dolphins are described as socialization (Simões-Lopes 1998) and bow-riding (Janik 2015). Bow-riding was reported as occurring during both daytime and nighttime by fishers from the Cagarras Archipelago (Rio de Janeiro) (Zappes et al. 2010) and without specifying the time of day by fishers in Rio Grande do Norte, São Paulo and Santa Catarina (Souza 2011). According to Janik (2015) bottlenose dolphins frequently travel at the bow of boats, as either a playful behavior or a sexual display. According to the same author, the behaviors of "rolling themselves up in the anchor line, circling and diving" and "pulling the boat" can be play too.

Despite humpback whales are only being present for five months of the year in the region, fishermen mentioned most of the behavioral displays that can be found in the literature (see Engel et al. 2016), indicating considerable knowledge of the behavior of this cetacean. Humpback whales are mentioned more often due to their body size, which attracts attention, and due to more frequent interaction with this animal, which permits greater recognition (Mourão et al. 2006).

Collaborative fishing between fishers and dolphins has been reported in different parts of the world, including Brazil, for Guiana dolphins (Souza 2011, Costa et al. 2012, Brito 2012, Manzan \& Lopes 2015) and bottlenose dolphins (Simões-Lopes et al. 1991, Peterson et al. 2008, Zappes et al. 2011a, Souza 2011). This type of behavior increases the fishers's contact with the animal, allowing them to build up empirical knowledge of the animals with which they coexist (Mourão et al. 2006).

The fishermen from Ilhéus believe that Guiana dolphins and bottlenose dolphins save people, including defending them from other potentially dangerous animals, such as sharks. These beliefs seem to generate positive attitudes among fishers towards these dolphins. Similar beliefs were recorded in Bahia (Zappes 2007), Pará (Brito 2012) and São Paulo (Souza 2011) for the Guiana dolphin and in Pará and São Paulo for the bottlenose dolphin (Souza 2011). The reports related to Guiana dolphins, bottlenose dolphins and humpback whales reveal changes over time, demonstrating that fishermen recognize the existence of a behavioral pattern associated with certain environmental conditions. For example, humpback whales breach and perform fin and tail slapping with greater frequency when the wind speed increases, permitting communications between and within groups when the noise from wind and waves interferes with acoustic communication (Kavanagh et al. 2017).

\section{Negative interactions}

Fishermen reported the intentional capture of small cetaceans by harpooning to serve as bait for shark fishing. In several regions of the world harpooning affects a number of cetacean species (Weir \& Pierce 2012, Quintana-Rizzo 2011). In Brazil, harpooning has been previously recorded, mainly in Pará (Siciliano 1994, 2008, Alves \& Rosa 2008, Brito et al. 2012). In Bahia, evidence of harpooning has been found in Itacaré (Alarcon et al. 2009), and in Canavieiras fishers explained that, in the past, cetaceans were often harpooned when following boats (Barbosa-Filho et al. 2016). Barbosa-Filho et al. (2018) recorded the use of dolphin fat for shark fishing by fishers in the south of Bahia.

According to the responses, there is a belief that the minke whale attacks people, mainly because of its behavior of approaching vessels. This has generated a negative attitude that is reflected in behaviors that can harm the animal. Confirming this behavior, researchers have characterized the minke whale (Balaenoptera acutorostrata) to be "friendly" due to its custom of approaching boats and swimmers on the Great Barrier Reef in Australia and interacting for hours (Arnold $\&$ Birtles 1999). It is likely that the respondents' lack of knowledge about the animal causes fear. The exchanges of knowledge between researchers and fishers can contribute to changing beliefs and improving the coexistence of fishers with minke whales and other cetaceans. This example illustrates the importance of understanding the community's perception of local fauna and the conflicts involved in order to efficiently contribute to educational programs (Silvano \& Begossi 2012).

When animals interfere with fishing, fishermen use a range of methods to drive them away or move to another fishing site, which requires more fuel and travel time. Fishers from a number of different communities in Brazil have reported driving away cetaceans to avoid accidents (e.g. Alarcon et al. 2009, Zappes et al. 2011b, 2013a, Silva et al. 2014).

Bycatch was mostly mentioned in relation to $S$. guianensis, which is considered to be the most vulnerable species to fishing nets along the Brazilian coast for being a coastal species (Borobia et al. 1991): there are records of bycatch of Guiana dolphins in the southeastern, northeastern and northern regions of Brazil (Siciliano 1994, Freitas-Netto \& Di Beneditto 2008, Alarcon et al. 2009, Zappes et al. 2009, Manzan \& Lopes 2015). Accidental capture (bycatch) of T. truncatus was reported by few fishermen; however, reports and memories of accidents suggest that bycatch does occur. Bycatch of T. truncatus in fishing nets has been reported by fishers in Brazil (Simões-Lopes 1998, Zappes et al. 2011b) and in other countries around the world (Weir \& Pierce 2012, Leeney et al. 2015, Revuelta et al. 2018). Fishers also denounced the bycatch of animals in "ghost nets". These pose a serious threat to marine animals as they continue to capture a diverse range of organisms in the coastal areas of the United States (Arthur et al. 2014) and Guatemala (Quintana-Rizzo 2011), amongst others. The most frequently mentioned accidents involved the entanglement of humpback whales in the line or rope. The fact that humpbacks get caught up in the line and usually tow the vessel causes insecurity and fear among the fishermen. Entanglement in the line has been described by fishers in the south of Bahia, Espírito Santo and Rio de Janeiro (Alarcon et al. 2009, Zappes et al. 2013b, Silva 
et al. 2014), who report that the presence of humpback whales hinders the use of this equipment. The loss or damage of fishing equipment causes financial losses for the fisherman, in addition to the loss of the fish catch, time and fuel. Humpback whales are found in the region in winter, which is not a good fishing season. The loss of fishing gear during a period of low profits may be especially difficult to handle for artisanal fishers.

For whales, the very thin nylon fishing line may not represent as serious a threat as the anchor rope or nets, which may hinder their swimming and feeding capacity (Johnson et al. 2005, Cassof et al. 2011). The friction of the nylon line dragging in the water may result in deep wounds that can penetrate through several layers of tissues, eventually reaching the bones (Moore et al. 2006). According to these authors, the wounds remain open, facilitating infection by pathogens. Pinheiro et al. (2015) reported a case of severe mutilation of the peduncle of a small whale entangled in a longline fishing gear off the southeastern coast of Brazil. In Bahia, humpback whales with nets or ropes attached to their bodies have been observed several times (Rocha-Campos et al. 2011).

The fishermen reported that collisions are more common at night. According to Zappes et al. (2013b), the whale-spotting capability of boat operators is practically zero during nighttime navigation. Although the vessels are small and easily maneuverable, accidents with boats have previously been recorded in Bahia, Espírito Santo and Rio de Janeiro (Marcondes \& Engel 2009, Zappes et al. 2013b, Silva et al. 2014). Collisions are reported in various different regions of the world, such as Africa (Weir \& Pierce 2012); Central America (Guzman et al. 2012) and the North Atlantic (Van Der Hoop et al. 2012). Accidents can cause internal or external injuries and even the death of the animals (Lagueux et al. 2011, Zappes et al. 2013b), as well as damaging the hull of the vessels. The damage caused to the vessel can generate a major economic loss for artisanal fishers, who are low-income workers (Queiroz 2012).

The participatory mapping aggregated relevant information represented graphically, an approach that facilitates management discussions among stakeholders (da Silva \& Verbicaro 2016). The map allowed to identify the areas where humpback whales are most frequently seen, where accidents occur, and the areas of overlap in the use of marine space by fishermen and whales. Opening the dialogue and allowing the exchange of information with local fishers may result in their greater commitment and help in the implementation of conservation objectives. A spatial understanding of accident sites and the types of accidents that occur provides a very rapid method of visualizing accident sites and identifying areas of potential conflict between fisheries and cetaceans. Furthermore, it can contribute to a more refined dialogue between institutions and fishing communities (Gerhardinger et al. 2010).

The impression of the fishermen is that the number of humpbacks has increased in the last decade. According to Souza (2015), fishers from Ilhéus have noticed the population growth of humpbacks in the region. According to Andriolo et al. (2010), the increasing population of humpback whales result in the occupation of new areas. As a consequence, the frequency of negative interactions is likely to increase and the consequences for both fishers and humpbacks needs to be considered. Studies carried out with fishing communities in Rio
Grande do Sul and southern Bahia indicate that conflicts between fishers and humpbacks are increasing (Zambonim et al. 2009, Zappes et al 2013a, b).

The fishermen responded that they do not know how to avoid accidents. According to Zappes et al. (2013a), to avoid conflicts with E. australis, fishers in Santa Catarina proposed the implementation of a closed season during the months that the species is present, alongside the development of whale watching activities. This last suggestion was also cited by Alarcon et al. (2009) as a way to reduce accidents with humpbacks in Itacaré. Nonetheless, the development perspectives of whale watching in Ilhéus are currently limited due to the low number of tourists during the austral winter and the low economic income of the local population. However, the development of whale watching with tourists can even replace fishing, an old activity, and result in new socioeconomic and cultural problems for the community. The implementation of a closed season would bring changes to the fishing industry. Fish is an important part of the culinary tradition of Bahia. If fishing is reduced or stopped during winter, then other sources of the product will have to be found to supply the municipality of Ilhéus. This would directly affect the local economy, which is partly based on the productive cycle of the local and regional fishing industry, involving economic dynamics that generate work and income for a large number of families in the municipality (Queiroz 2012). Alternative economic activities that may favor the valuation and conservation of cetaceans in the region are desirable, but according to Alves \& Rosa (2008), understanding the socioeconomic aspects involved is important for the development of any successful management plan.

Other possible solutions to avoid accidents should be analyzed and discussed among the local fishing community, researchers and environmental agencies, such as IBAMA (Brazilian Institute of the Environment and Renewable Natural Resources), directing efforts to improve the commitment of stakeholders to successfully implement co-management strategies. According to Souza \& Begossi (2007), socio-environmental conflicts can only be resolved with the contribution of local perception, which is a product of the beliefs and practices in the territory in order to value and strengthen the culture of the local community (Gerhardinger et al. 2010).

Many fishermen interviewed in Ilhéus have a positive perception about cetaceans, know the areas where the accidents occur and want to avoid them. This study shows that fishers can contribute substantially to the development of research on cetaceans and that they are essential in the development of management plans suited to the local reality. To minimize negative interactions between fishermen and cetaceans in Ilhéus, it is necessary to understand the socio-environmental relations involved in the interactions, in order to support the elaboration of measures that contribute to the conservation of cetaceans and the sustainability of fishing (Silvano \& Begossi 2012). We recommend the development of a participatory environmental education program (e.g. Zappes et al. 2016) to increase understanding of the importance of cetaceans in the ecosystem, as well as to value local knowledge and traditions related to marine mammals. Systematic monitoring programs should be conducted with fishers on negative interactions in order to identify the species and number of animals involved in accidents. 


\section{Conclusion}

The fishermen from Ilhéus described both positive and negative interactions with cetaceans in their fishing grounds. The negative interactions affect both the practice of fishing in the region, through damage to fishing equipment, and the cetaceans, causing injury or death. The animals most cited as sources of negative interactions were: the Guiana dolphin as bycatch and the humpback whale for entanglement, dragging of boats and collision.

Estimates of accidents based on the fisher's memories provide a sense of the scale of negative interactions. Considering the increase in the humpback whale population and the "vulnerable" conservation status of the Guiana dolphin, it is necessary to strengthen relations between researchers and the fishing community in Ilhéus to develop studies focusing on these conflicts. As a result, interactions could be monitored to assess the impact on fishing activity and cetacean populations. With the exception of the minke whale, the fishermen have a relatively positive view of cetaceans and would like to avoid accidents. They have shown themselves to be participative and open with the research. This indicates that they are willing to contribute to research with these animals.

We also suggest strengthening knowledge exchange between researchers and fishers, since academic knowledge about the behavior of some species, such as the minke whale, could facilitate the coexistence of fishers with these animals. Information provided by fishers and reported in this paper could contribute to the definition of participatory conservation strategies to reduce accidents between artisanal fishers and cetaceans.

\section{Acknowledgements}

This study was financed in part by the Coordenação de Aperfeiçoamento de Pessoal de Nível Superior - Brasil (CAPES) - Finance Code 001. We are grateful to IDEA WILD for small equipment donation. To Professors Alexandre Schiavetti and Daniela Alarcon Triguerinho for contributions made throughout the research. To the presidents of the colonies for their collaboration and to the fishermen from Ilhéus for their participation in the study. To Kaique Britos for the elaboration of the map.

\section{Author Contributions}

Cecilia Inés Seminara data collection; Substantial contribution to all steps of the research from concept and design of the study to manuscript preparation.

Márcio Luiz Vargas Barbosa-Filho: Substantial contribution to all steps of the research from concept and design of the study to manuscript preparation.

Yvonnick Le Pendu: Substantial contribution to all steps of the research from concept and design of the study to manuscript preparation.

\section{Conflict of Interest}

The authors declare that they have no conflict of interest related to the publication of this manuscript.

\section{Ethics}

As informed in the manuscript Material and Methods section of the manuscript, data collection began after approval was given by the Ethics Committee (CEP-CONEP n ${ }^{\circ}$ 68007516.9.0000.5526). The nature and purpose of the research was explained to each fisher and they were each provided with a Free and Informed Consent Form, in order to establish whether they would like to contribute to the research, with permission requested for anonymous recording of information.

\section{References}

ALARCON, D.T., DÂMASO, R.C. da S.C. \& SCHIAVETTI, A. 2009. Abordagem etnoecológica da pesca e captura de espécies não-alvo em Itacaré, Bahia (Brasil). Bol. do Inst. Pesca. 35(4):675-686.

ALBUQUERQUE, U.P., RAMOS, A.M., LUCENA, R.F.P. \& ALENCAR, R.N. 2014. Methods and Techniques Used to Collect Ethnobiological Data. In: Albuquerque, U.P., Cunha, L.V.F.C., Lucena, R.F.P., Alves, R.R.N. (Eds.) Methods and Techniques in Ethnobiology and Ethnoecology (First edition) New York, Springer Protocols Handbooks, pp.15-37.

ALVES, R.R.N. \& ROSA, I.L. 2008. Use of Tucuxi dolphin Sotalia fluviatilis for medicinal and magic/religious purposes in North of Brazil. Hum. Ecol. 36(3):443-447.

ANDRIOLO, A., KINAS, P., ENGEL, M., ALBUQUERQUE MARTINS, C. \& RUFINO, A. 2010. Humpback whales within the Brazilian breeding ground: distribution and population size estimate. Endanger. Species Res. 11(3):233-243.

ARNOLD, P.W. \& BIRTLES, R.A. 1999. Towards sustainable management of the developing dwarf minke whale tourism industry in northern Queensland. CRC Reef Research Centre. Technical Report, n. 27. Townsville. 30p.

ARTHUR, C., SUTTON-GRIER, A.E., MURPHY, P. \& BAMFORD, H. 2014. Out of sight but not out of mind: Harmful effects of derelict traps in selected U.S. coastal waters. Mar. Pollut. Bull. 86(1-2):19-28.

BARBOSA-FILHO, M. L.V. \& CETRA, M. 2007. Dinâmica da frota pesqueira sediada na cidade de Ilhéus, estado da Bahia. Bol. Técnico-Científico do CEPENE, Tamandaré, 15(2):99-105.

BARBOSA-FILHO, M.L.V., COSTA-NETO, E.M. \& DANILEWICZ, D. 2016. Dolphin harpooning off the coast of Bahia, Brazil. Mar. Biodivers. Rec. 9(1):42.

BARBOSA-FILHO, M.L.V., BARRETO, R.M.F., SICILIANO, S., SEMINARA, C. \& COSTA-NETO, E.M. 2018. Use of cetaceans as bait in southern Bahia, Brazil, by expert fishermen that market shark fins: a lucrative trade and two threatened zoological groups. Ethnobiology letters. 9(2):12-18. DOI 10.14237/eb1.9.2.2018.953

BATISTA, R.L.G.L.G., SCHIAVETTI, A., SANTOS, U.A. \& REIS, M. do S.S. dos. 2012. Cetaceans registered on the coast of Ilhéus (Bahia), northeastern Brazil. Biota Neotrop. (Edição em Port. Online) 12(1):bn00312012012.

BIERNACKI, P. \& WALDORF, D. 1981. Snowball sampling-problems and techniques of chain referral sampling. Sociol. Method. Res. 10:141-163.

BITTENCOURT, A., DOMINGUEZ, J., MARTIN, L., SILVA, I., CARLOS, A., SILVA, D.A., BITTENCOURT, P., MARIA, J. \& DOMINGUEZ, L. 2000. Patterns of sediment dispersion coastwise the State of Bahia - Brazil. An. Acad. Bras. Cienc. 72(2):271-287.

BOROBIA, M., SICILIANO, S. \& LODI, L.F. 1991. Distribution of the South American dolphin Sotalia fluviatilis. Can. J. Zool. 69:1025-1039.

BRASIL. 1979. Carta Náutica $\mathrm{N}^{\circ} 1200$ - do Porto de Ilhéus a ponta de Cumuruxatiba. Diretoria de Hidrografia e Navegação. Mar. do Bras.

BRASIL. 2009. Lei 11959 de 29 de junho de 2009. Dispõe sobre a Política Nacional de Desenvolvimento Sustentável da Aquicultura e da Pesca, regula as atividades pesqueiras. Diário Oficial Da União, Brasília, Seção 1, p.1.

BRITO, T. 2012. O conhecimento ecológico local e a interação de botos com a pesca no litoral do estado do Pará, região Norte - Brasil. Biotemas. 25(4):259-277. 
CARLSSON, L. \& BERKES, F. 2005. Co-management: concepts and methodological implications. J Environ Manage. 75:65-76.

CASSANO, C.R., ALMEIDA-ROCHA, J.M. de, ALVAREZ, M.R., BERNARDO, C.S.S., BIANCONI, G.V., CAMPIOLO, S., CAMPOS, C.B. De, DANILEWICZ, D., FALCÃO, F.D.C., GARCÍA, F.V., GINÉ, G.A.F., GUIDORIZZI, C.E., JERUSALINSKY, L., LE PENDU, Y., MARCONDES, M.C.C., MELO, V.L., MENDES, F.R., MIRETZKI, M., NEVES, L.G., OLIVEIRA, L.C., PEREIRA, A.R., SILVA, K.F.M. da, REIS, M.S. do, VLEESCHOUWER, K.M. De, VIEIRA, E.M., XIMENES, G.E.I. 2017. Primeira avaliação do status de conservação dos mamíferos do estado da Bahia, Brasil. Oecologia Aust. 21(2):156-170.

CASSOFF, R.M., MOORE, K.M., MCLELLAN, W.A., BARCO, S.G., ROTSTEIN, D.S. \& MOORE, M.J. 2011. Lethal entanglement in Baleen Whales. Dis. Aquat. Organ. 96:175-185.

COSTA, M.E.B., LE PENDU, Y. \& NETO, E.M.C. 2012. Behaviour of Sotalia guianensis (van Bénéden, 1864) (Cetacea, Delphinidae) and ethnoecological knowledge of artisanal fishermen from Canavieiras, Bahia, Brazil. J. Ethnobiol. Ethnomed. 8(1):18.

da SILVA C.N. \& VERBICARO C.C. 2016. O mapeamento participativo como metodologia de análise do território. Scientia Plena 12(6). doi: 10.14808/ sci.plena.2016.069934

DALLA ROSA, L. \& SECCHI, E.R. 2007. Killer whale (Orcinus orca) interactions with the tuna and swordfish longline fishery off southern and southeastern Brazil: a comparison with shark interactions. J. Mar. Biol. Assoc. U. K. 87:135-140.

De MASTER, D.P., FOWLER, C.W., PERRY, S.L. \& RICHLEN, M.F. 2001. Predation and competition: the impact of fisheries on marine-mammal populations over the next one hundred years. J. Mammal. 82:641-651.

DIEGUES, A.C.S. 2000. Etnoconservação. Novos rumos para a conservação da natureza nos trópicos. HUCITEC/NUPAUB/USP, São Paulo.

ENGEL, M., FERNANDES, L. \& CIPOLOTTI, S. 2016. Observação de baleias na Bahia: Identificação e boas práticas. Bambu 1ra ed. 1-96p.

FREITAS-NETTO, R. \& DI BENEDITTO, A.P. 2008. Interactions between fisheries and cetaceans in Espírito Santo State coast, southeastern Brazil. Zoociências. 10(1) :55-63.

FONTANELLA, J.B., LUCHESI, B.M., SAIDEL, M.G.B., RICAS, J., TURATO, E.R. \& MELO, D.G. 2011. Sampling in qualitative research: a proposal for procedures to detect theoretical saturation. Cad. Saúde Pública 27 (2):389-394.

GERHARDINGER, L.C., GODOY, E.A., DAPPER, C.G., CAMPOS, R., MARCHIORO, G.B., SFORZA, R. \& POLETTE, M. 2010. Mapeamento participativo da paisagem marinha no Brasil experiências e perspectivas. In: Albuquerque, U.P.; Lucena, R.; Cunha, Luiz Vital Fernandes Cruz da. (Org.). Métodos e Técnicas na Pesquisa Etnobiológica e Etnoecológica. Recife: NUPEEA, 109-149p.

GROCH, K.R., PALAZZO JR., J.T., FLORES, P.A.C., ADLER, F.R. \& FABIAN, M.E. 2005. Recent rapid increases in the right whale (Eubalaena australis) population off southern Brazil. Lat. Am. J. Aquat. Mamm. 4(1):41-47.

GUZMAN, H.M., GOMEZ, C.G. \& GUEVARA, C.A. 2012. Potential vessel collisions with Southern Hemisphere humpback whales wintering off Pacific Panama. Mar. Mam. Sci. volume DOI: 10.1111/j.1748-7692.2012.00605.x

HAYS, T. 1976. An empirical method for the identification of cover categories in ethnobiology. Am. Ethnol. 3(3):489-507.

INTERNATIONAL WHALES COMMISSION (IWC). 2016. O Atlântico Sul: um santuário para as baleias. Documento submetido ao encontro do Comitê científico, Bled, Slovenia, junho 2016, para revisão. Agenda proposta para consideração no $66^{\circ}$ encontro annual da CIB, Portoroz, Slovenia em Outubro de 2016. Portoroz, Slovenia.

IZIDORO, F.B. \& LE PENDU, Y. 2012. Estuarine dolphins (Sotalia guianensis), Cetacea, Delphinidae) play at Porto de Ilhéus harbor, Bahia, Brazil. Panam. J. Aquat. Sci. 7(1):27-36.

JANIK, V.M. 2015. Play in dolphins. Curr. Biol. 25(1):7-8. http://dx.doi. org/10.1016/j.cub.2014.09.010.
JOHNSON, A., SALVADOR, G., KENNEY, J., ROBBINS, J., KRAUS, S., LANDRY, S. \& CLAPHAM. P. 2005. Fishing gear involved in entanglements of right and humpback whales. Mar. Mam. Sci. 21:635-645.

KAVANAGH, A.S., OWEN, K., WILLIAMSON, M.J., BLOMBERG, S.P., NOAD, M.J., GOLDIZEN, A.W., KNIEST, E., CATO, D.H. \& DUNLOP, R.A. 2017. Evidence for the functions of surface-active behaviors in humpback whales (Megaptera novaeangliae). Mar. Mam. Sci. 33(1):313334. DOI: $10.1111 / \mathrm{mms} .12374$

LAGUEUX, K.M., ZANI, M.A., KNOWLTON, A.R. \& KRAUS, S.D. 2011. Response by vessel operators to protection measures for right whales Eubalaena glacialis in the southeast US calving ground. Endanger. Species Res. 14:69-77.

LEENEY, R. H., DIA, I. M. \& DIA, M. 2015. Food, Pharmacy, Friend? Bycatch, Direct Take and Consumption of Dolphins in West Africa. Hum. Ecol. 43(105). https://doi.org/10.1007/s10745-015-9727-3

MANZAN, M.F. \& LOPES, P.F.M. 2015. Fishers' knowledge as a source of information about the estuarine dolphin (Sotalia guianensis, van Bénéden, 1864). Environ. Monit. Assess. 187:4096-4110.

MARCONDES, M.C.C. \& ENGEL, M.H. 2009. Ship strikes with humpback whales in Brazil. In International Whaling Commission 61 Meeting, v. SC/61/BC4 Madeira, Portugal.

MARSHALL, B., CARDON, P., PODDAR, A. \& FONTENOT, R. 2013. Does Sample Size Matter in Qualitative Research?: a review of qualitative interviews in is research. J. Comput. Inform. Syst. 54(1), 11-22. doi:10.10 80/08874417.2013.11645667

MASON, M. 2010. Sample size and saturation in PhD studies using qualitative interviews. Forum Qualitative Sozial forschung / Forum: Qualitative Soc. Res. 11(3). http://nbn-resolving.de/urn:nbn:de:0114-fqs100387.

MEDEIROS, P.M., ALMEIDA, A.L.S., LUCENA, R.F.P.; SOUTO, F.J.B. \& ALBUQUERQUE, U.P. 2014. Use of Visual Stimuli in Ethnobiological Research. In: Albuquerque, U.P., Cunha, L.V.F.C., Lucena, R.F.P. \& Alves, R.R.N. (Eds.) Methods and Techniques in Ethnobiology and Ethnoecology (First edition) New York, Springer Protocols Handbooks. 87-98p.

MONTEIRO-FILHO, E.L.A. et al. Guia Ilustrado de Mamíferos Marinhos do Brasil. Instituto de pesquisa Cananéia (IPeC). 106f. 1 ed. 2013.

MOORE, M.J., BOGOMOLNI, A., BOWMAN, R., HAMILTON, P.K., HARRY, C.T., KNOWLTON, A.R., LANDRY, S., ROTSTEIN, D.S. \& TOUHEY, K. 2006. Fatally entangled right whales can die extremely slowly. Oceans. DOI: 10.1109/OCEANS.2006.306792

MOURÃO, J.S., ARAÚJO, H.F.P. \& ALMEIDA, F.S. 2006. Ethnotaxonomy of mastofauna as practiced by hunters of the municipality of Paulista, state of Paraíba-Brazil. J. Ethnobiol. Ethnomed. 2(19). doi:10.1186/1746-4269-2-19.

NORTHRIDGE, S.P. 1984. World review of interactions between marine mammals and fisheries International Institute for Environment and Development London, U.K. FAO. Disponível em: http://www.fao.org/ docrep/003/x6860e/X6860E08.htm. Acesso em: 17 jul. 2018.

PETERSON, D., HANAZAKI, N. \& SIMÕES-LOPES, P.C. 2008. Natural resource appropriation in cooperative artisanal fishing between fishermen and dolphins (Tursiops truncatus) in Laguna, Brazil. Ocean Coast. Manag. 51(6):469-475.

PINHEIRO, L. \& CREMER, M. 2003. Etnoecologia e captura acidental de golfinhos (Cetacea: Pontoporidae e Delphinidae) na Baía da Babitonga, Santa Catarina. Desenvolv. e Meio Ambient. 869-875.

PINHEIRO, F.C.F., SICILIANO, S., DE MOURA, J.F. \& TAVARES, D.C. 2015. Severe mutilation of a baleen whale in a longline fishery off the Brazilian coast. Mar. Biodivers. Rec. 8. doi:10.1017/s175526721500041x

QUEIROZ, G.A. 2012. Os dois circuitos da economia urbana na cidade de ilhéus: o circuito inferior da pesca. Caminhos de Geografia. 13(41):223-230. Disponível em: http://www.seer.ufu.br/index.php/caminhosdegeografia/ article/view/16622/9241.Acesso em: 01 jul. 2018.

QUINTANA-RIZZO, E. 2011. Harpooning and entanglement of wild dolphins in the Pacific coast of Guatemala. LAJAM. 9(2):179-182. http://dx.doi. org/10.5597/lajam00187 
RAMIRES, M., CLAUZET, M., ROTUNDO, M.M. \& BEGOSSI A. 2012. A pesca e os pescadores artesanais de Ilhabela (SP), Brasil. Bol. Inst. Pesca, São Paulo, 38(3): 231-246.

READ, A.J., DRINKER, P. \& NORTHRIDGE, S. 2006. Bycatch of Marine Mammals in U.S. and Global Fisheries. Conserv. Biol. 20(1):163-169.

REVUELTA, O., DOMĖNECH, N., FRAIJA-FERNÁNDEZ, N., GONZALBES, P., NOVILLO, O., PENADÉS-SUAY, J. \& TOMÁS, J. 2018. Interaction between bottlenose dolphin (Tursiops truncatus) and artesanal fisheries in the Valencia region (Spanish Mediterranean Sea). Ocean Coast Manage. 165:117-125.

ROCHA-CAMPOS, C.C., MORENO, I.B., ROCHA, J.M. da, PALAZZO-JR, J.T., GROCH, K.R., DE OLIVEIRA, L.R., GONÇALVES, L., ENGEL, M.H., MARCONDES, M.C.C., MUELBERT, M.M.C., OTT, P.H. \& DA SILVA, V.M.F. 2011. Plano de Ação Nacional para Conservação dos Mamíferos Aquáticos - Grandes Cetáceos e Pinípedes - Instituto Chico Mendes de Conservação da Biodiversidade - ICMbio

RODRIGUES, A.L.F. \& SILVA, M.L. 2012. Botos: realidade e fantasia na concepção de estudantes ribeirinhos do estado do Pará, Brasil. Natural Resources. 2(1):29-43. DOI: 10.6008/ESS2237-9290.2012.001.0003

SICILIANO, S. 1994. Review of small cetaceans and Fishery interactions in Coastal Waters of Brazil. Rep. Int. Whal. Comm. 15:241-250.

SICILIANO, S., EMIN-LIMA, N.R., COSTA, A.F., RODRIGUES, A.L.F., MAGALHÃES, F.A., TOSI, C.H., ... \& SILVA-JR, J.S. 2008. Revisão do conhecimento sobre os mamíferos aquáticos da costa Norte do Brasil. Arq. Mus. Nac. Rio de J. 66(2):381-401.

SILVA, C.V., MOREIRA, S.C., ZAPPES, C.A. \& DI BENEDITTO, A.P.M. 2014. Pesca artesanal e cetáceos que ocorrem no litoral leste do Rio De Janeiro: Uma abordagem etnoecológica para verificar a existência de manejo tradicional. Bol. do Inst. Pesca 40(4):521-539.

SILVANO, R.A.M. \& BEGOSSI, A. 2002. Ethnoichthyology and fish conservation in the Piracicaba River (Brazil). Journal of Ethnobiology. 22(2):285-306

SILVANO, R.A.M. \& BEGOSSI, A. 2012. Fishermen's local ecological knowledge on Southeastern Brazilian coastal fishes: contributions to research, conservation, and management. Neotropical Ichthyology. 10(1):133-147.

SIMÕES-LOPES, P.C. 1991. Interaction of coastal populations of Tursiops truncatus (Cetacea, Delphinidae) with the mullet artisanal fisheries in Southern Brazil. Biotemas. 4(2):83-94.

SIMÕES-LOPES, P.C., FÁBIAN, M.E. \& MENEGHETI, J.O. 1998. Dolphin interactions with the mullet artisanal fishing on southern Brazil: a qualitative and quantitative approach. Rev. Bras. Zoo. 15(3):709- 726.

SOUZA, P.S. 2015. Síndrome do deslocamento referencial entre gerações de pescadores em Ilhéus, Bahia. Dissertação de mestrado, Universidade Estadual de Santa Cruz, Ilhéus.

SOUZA, S.P. 2011. Etnobiologia de cetáceos por pescadores artesanais da Costa Brasileira. Tese de doutorado, Universidade Estadual de Campinas, São Paulo.

SOUZA, S.P. \& BEGOSSI, A. 2007. Whales, dolphins or fishes? The ethnotaxonomy of cetaceans in São Sebastião, Brazil. J. Ethnobiol. Ethnomed. 3(9). DOI: 101186/1746-4269-3-9
VAN DER HOOP, J.M., MOORE, M.J., BARCO, S.G., COLE, T.V.N.N., DAOUST, P.Y., HENRY, A.G., MCALPINE, D.F., MCLELLAN, W.A., WIMMER, T. \& SOLOW, A.R. 2012. Assessment of Management to Mitigate Anthropogenic Effects on Large Whales. Conserv. Biol. 27(1):121133. DOI: $10.1111 / j .1523-1739.2012 .01934 . x$

WARD, E., ZERBINI, A.N., KINAS, P.G., ENGEL, M.H. \& ANDRIOLO, A. 2011. Estimates of population growth rates of humpback whales (Megaptera novaeangliae) in the wintering grounds off the coast of Brazil (Breeding Stock A). J. Cetacean Res. Manag. 3:145-149.

WEIR, C. R. \& PIERCE, G. J. 2012. A review of the human activities impacting cetaceans in the eastern tropical Atlantic. Mammal Rev. 43:258-274. DOI:10.1111/j.1365-2907.2012.00222.x

ZAMBONIM, R., WEDEKIN, L. \& FARIAS, U.A. 2009. Nova Cartografia Social dos Povos e Comunidades Tradicionais do Brasil: comunidade de pescadores de Caravelas, Sul da Bahia. De Almeida, A.W.B.; Marim, R.A.; Neto, J.S. (coord.). Caravelas, BA: Casa 8 Desing/Editora Universidade Federal do Amazonas, 2009. 12p.

ZAPPES, C.A. Estudo etnobiológico comparativo do conhecimento popular de pescadores em diferentes regiões do litoral brasileiro e implicações para a conservação do boto-cinza Sotalia guianensis (Van Bénéden, 1864) (Cetacea, Delphinidae). 161f. Dissertação (Mestrado em Ciências Biológicas) - Universidade Federal de Juiz de Fora, Minas Gerais. 2007.

ZAPPES, C.A., ANDRIOLO, A., SILVA, F.O. \& MONTEIRO-FILHO, E.L.A. 2009. Potential conflicts between fishermen and Sotalia guianensis (van Bénéden, 1864) (Cetacea, Delphinidae) in Brazil. Sitientibus Série Ciências Biológicas. 9(4): 208-214.

ZAPPES, C.A., EDUARDO, C., GATTS, N., LODI, L.F., ANDRIOLO, A., PAULA, A. \& DI BENEDITTO, A.P.M. 2010. Descrição do comportamento de Tursiops truncatus Montagu, 1821 (Cetacea: Delphinidae) através da etnoecologia e da logica Fuzzy. Rev. Bras. Zoociências 12(3):291-304.

ZAPPES, C.A., ANDRIOLO, A., SIMÕES-LOPES, P.C. \& DI BENEDITTO, A.P.M. 2011a. "Human-dolphin (Tursiops truncatus Montagu, 1821) cooperative fishery" and its influence on cast net fishing activities in Barra de Imbé/Tramandaí, Southern Brazil. Ocean Coast. Manag. 54(5):427-432.

ZAPPES, C.A., HOFFMANN, L.S., MORÓN, S., FRUET, P.F. \& LAPORTA, P. 2016. Report of the Working Group on Ethnobiology and Environmental Education related to Tursiops truncatus in the Southwest Atlantic Ocean. LAJAM. 11(1-2): 99-105. http://dx.doi.org/10.5597/lajam00219

ZAPPES, C.A., GATTS, C.E.N., LODI, L., ANDRIOLO, A. \& DI BENEDITTO, A.P.M. 2011b. Interações entre o golfinho-nariz-de-garrafa (Tursiops truncatus) e a pesca artesanal no Arquipélago das Cagarras e áreas adjacentes, Rio de Janeiro, Brasil. Sitientibus série Ciências Biológicas. 11(1):24-30

ZAPPES, C.A., SILVA, C.V., PONTALTI, M., DANIELSKI, M.L. \& DI BENEDITTO, A.P.M. 2013a. The conflict between the southern right whale and coastal fisheries on the southern coast of Brazil. Marine Police. 38:428-437.

ZAPPES, C.A., ALVES, L.C.P.S., SILVA, C.V., AZEVEDO, A.F., DI BENEDITTO, A.P.M. \& ANDRIOLO, A. 2013b. Accidents between artisanal fisheries and cetaceans on the Brazilian Coast and Central Amazon proposals for integrated management. Ocean Coast. Manage. 85:46-57. 